\title{
Effect of Phyllanthus niruri Extract on Low Density Lipoprotein of Dyslipidemic White Rats (Rattus norvegicus)
}

\section{Anastasia Feliciana ${ }^{1 *}$, Andre Stefanus ${ }^{1}$, Felix Evanda ${ }^{1}$, Yosua Anthony $\mathbf{P}^{1}$, lin Suryanti ${ }^{1}$, Ahmad Ghozali $^{2}$, Rita Cempaka $S^{2}$ and Indrawati $F^{2}$}

${ }^{1}$ Department of Medicine Study Program, Public Health and Nursing, Gadjah Mada University, Yogyakarta, Indonesia

${ }^{2}$ Department of Anatomical Pathology, Public Health and Nursing, Gadjah Mada University, Yogyakarta, Indonesia

${ }^{*}$ Corresponding author: Anastasia Feliciana, Department of Medicine Study Program, Faculty of Medicine, Public Health and Nursing, Gadjah Mada University, Yogyakarta, Indonesia, Tel: +6282137945637; E-mail: anastasia_feliciana@mail.ugm.ac.id

Received date: September 20, 2019; Accepted date: October 04, 2019; Published date: October 11, 2019

Citation: Feliciana A, Stefanus A, Evanda F, Anthony PY, Suryanti I, et al. (2019) Effect of Phyllanthus niruri Extract on Low Density Lipoprotein of Dyslipidemic White Rats (Rattus norvegicus). Herb Med Vol.5 No.2:6.

Copyright: (c) 2019 Feliciana A, et al. This is an open-access article distributed under the terms of the Creative Commons Attribution License, which permits unrestricted use, distribution, and reproduction in any medium, provided the original author and source are credited.

\section{Abstract}

Background: Dyslipidemia is a lipid metabolism disorder characterized by elevated levels of total cholesterol, Low Density Lipoprotein (LDL) and triglycerides and a decrease in high-density lipoprotein (HDL). Meniran contains tannins, saponins, alkaloids, rutin and quercetin, which have hypolipidemia effect.

Objective: This study aimed to observe the effect of meniran extract on the Low Density Lipoprotein (LDL) in Wistar rats, compared with simvastatin.

Methods: Thirty-five Wistar rats (Rattus novergicus) were divided into five groups, then all were induced with American Diet 2 (AD2) high fat modification diet for 60 days, except the control group I. Then during the next 60 days, groups I and II were not given any treatment, group III was given simvastatin $0.8 \mathrm{mg} / 200 \mathrm{~g}$ body weight (BW)/ day, group IV was given meniran extract $50 \mathrm{mg} / 200 \mathrm{~g}$ $\mathrm{BW} /$ day and group $\mathrm{V}$ was given meniran extract 100 $\mathrm{mg} / 200 \mathrm{~g}$ BW/day.

Results: Meniran therapy $50 \mathrm{mg} / 200 \mathrm{~g} \mathrm{BW} /$ day was better in lowering LDL level than meniran dose $100 \mathrm{mg} / 200 \mathrm{~g}$ BW/day. Meniran therapy, which was significantly $(p<0.05)$ better than simvastatin, was meniran dose of 50 $\mathrm{mg} / 200 \mathrm{~g}$ BW/day in lowering LDL.

Conclusion: Meniran therapy $50 \mathrm{mg} / 200 \mathrm{~g}$ BW/day can lower LDL level significantly. In this dose meniran decreased LDL better than simvastatin.

Keywords: Phyllanthus niruri extract; Lipid profile; Wistar rat; Dyslipidemia; Simvastatin

\section{Introduction}

Dyslipidemia is a disorder of fat metabolism marked by increase in one or more of the fraction of blood fats, such as cholesterol, cholesterol esters, phospholipids, and triglycerides. According to the World Health Organization (WHO), approximately $39 \%$ of the world population was suffering from hypercholesterolemia [1]. Thirty-four million Americans have dyslipidemia with total cholesterol over 240 $\mathrm{mg} / \mathrm{dl}$ (American Heart Association) at a cost of US \$400 billion. According to research by Kamso et al. severe dyslipidemia cases in Indonesia with total cholesterol levels $\geq$ $240 \mathrm{mg} / \mathrm{dl}$ are most prevalent in Jakarta and Padang (>56\%) [2].

An alternative therapy with lesser side effects would be useful, one of which is the extract from meniran herb (Phyllanthus niruri). Meniran (Phyllanthus niruri) contains various active compounds such as flavonoids, lignin, tannins, alkaloids, saponins and terpenoids [3]. Meniran's active compounds in the extract that can reduce levels of cholesterol and lipids are saponins, and alkaloids [4].

In a previous study, Kahono concluded that meniran (Phyllantus niruri) significantly lowered triglycerides in Rattus norvegicus rat with induced dyslipidemia with a dose of 100 $\mathrm{mg} / 200 \mathrm{~g} \mathrm{BW} /$ day [5]. Khanna et al. revealed that meniran herbs can lower very low density lipoprotein (VLDL) and low density lipoprotein (LDL) levels in white rats at dose of 250 $\mathrm{mg} / \mathrm{kg}$ in mice simultaneously fed cholesterol $(25 \mathrm{mg} / \mathrm{kg})[6]$.

\section{Materials and Methods}

\section{Meniran extract preparation}

Meniran extract was derived from the extraction of herbaceous meniran plant (Phyllantus niruri) leaf in Lembaga Penelitian dan Pengujian Terpadu (LPPT) Unit I, Universitas Gadjah Mada (UGM), Yogyakarta. Samples were obtained from 
Merapi Farma, Palagan Street, Tentara Pelajar km 8.8, Sleman, Yogyakarta.

Meniran extract was obtained by the extraction from dried meniran leaves using $70 \%$ ethanol by maceration techniques in LPPT Unit I, UGM, Yogyakarta. Meniran leaves were made into simplicia by drying at room temperature. After drying, the material was made into powder until smooth and then filtered through a sieve to obtain a homogeneous powder. This homogeneous powder was extracted by maceration. Maceration was done by soaking and stirring the powder in liquid (ratio of 1 part powder and 9 parts fluid) for approximately 5 days. This made the active substances from the cell cavity dissolve as a result of different concentrations. Then the active substances went out of the cell. After that the solution was filtered, and the residue was added by fluid until the water became colorless. Finally, the liquid was concentrated by ethanol evaporator until exhausted [7].

Meniran extracts were given in two doses to two different groups: $50 \mathrm{mg} / 200 \mathrm{~g}$ body weight/day and $100 \mathrm{mg} / 200 \mathrm{~g}$ body weight/day. The meniran extract was given orally sonded to animal models every day in the morning.

\section{Preparation of simvastatin}

Simvastatin was obtained from a local pharmacy and the dilution carried out in the Laboratory of Pharmacology, Faculty of Medicine, Public Health and Nursing, UGM.

The dose used for humans was $40 \mathrm{mg} /$ day, after being converted to white rats it weighed 200 grams, dose of simvastatin in rats $=0.018 \times 40 \mathrm{mg} / 200 \mathrm{~g}$ body weight of rat/ day $=0.72 \mathrm{mg} / 200 \mathrm{~g}$ body weight of rat/day $\approx 0.8 \mathrm{mg} / 200 \mathrm{~g}$ body weight rat/day. The conversion factor per ratio of human body weight to rat body weight is 0.018 to 1 .

\section{Provision and adaptation animals model}

The study has been approved by the Medical and Health Research Ethics Committee, Faculty of Medicine, Universities Gadjah Mada (Ref: KE/FK/434/EC). The animal models used in this experiment were thirty-five Wistar rats, which were obtained from LPPT UGM with the following inclusion criteria. Those rats were divided randomly into five cages. Rats were fed in a cage, with each cage containing one group of mice consisting of 7 rats, with cage size at (length $\times$ width $\times$ height $)=(40 \mathrm{~cm} \times 30 \mathrm{~cm} \times 20 \mathrm{~cm})$. Rats in each group underwent an adaptation for one week before the blood sampling to check the levels of LDL. During the adaptation period, mice were given AD2 feed ad libitum and distilled water, with lighting for 12 hours. Room temperature ranged between $21^{\circ} \mathrm{C}-25^{\circ} \mathrm{C}$ and humidity range $67 \%-81 \%$. After the adaptation period, the rats were fasted for 12 hours to take blood samples.

\section{Blood sampling procedure}

Before the blood samples were drawn, rats were fasted for 12 hours. At the time of blood sampling, rats were anesthetized with ketamine $0.2 \mathrm{mg} / \mathrm{ml}$ that was given as 0.3 $\mathrm{ml}$ per rat. Anesthetic effects appeared 15 minutes after the administration of anesthesia. Once the animal models were anesthetized, they were held by hand to perform blood sampling by inserting a capillary tube with a $45^{\circ}$ angle carefully into the medial canthus and rotated to break bulbar conjunctiva by reaching the orbital bone and rupturing the orbital sinus. Blood was taken as much as 1-3 $\mathrm{ml}$ through the orbital plexus media, and samples were collected in containers that were properly labeled. Subsequently, the samples were sent to the LPPT UGM laboratory for LDL level measurement.

\section{Dyslipidemia induction}

Dyslipidemia induction was done by providing as much as 10\% lard in American Diet 2 (AD2) standard food to groups II, III, IV, and V. Those rats were divided randomly. The first group was fed with standard food AD2. Induction of dyslipidemia is intended to increase LDL. After 60 days of induction, LDL level was checked.

\section{LDL level measurement}

LDL examination was conducted by direct method. In the direct method, the first step was precipitating reagent deposition. After being incubated for 10 minutes at $15^{\circ} \mathrm{C}-25^{\circ} \mathrm{C}$, sample was centrifuged for 15 minutes at 4000 rotations per minute (rpm). The supernatant was taken and mixed with the reaction solution. Then the sample was incubated for 10 minutes at $15^{\circ} \mathrm{C}-25^{\circ} \mathrm{C}$ and the absorbance was measured [8].

\section{Data analysis}

Statistical evaluation was done by using the SPSS statistical program. Data were presented as mean \pm standard deviation. First, the data were tested with the Shapiro-Wilk test for normality distribution test. If the distribution was normal, data was analyzed using One Way ANOVA with a significance level of $95 \%$. If the data from One Way ANOVA was significant $(p<0.05)$, the Post Hoc Test was conducted using Tukey HSD, followed by Paired T Test to assess changes in the pre and post-test in the same group. If the data were not normally distributed, transformation was performed. If the data were still not normal, analysis was continued with non-parametric Kruskal-Wallis tests to assess the significance of differences between groups and Wilcoxon tests to assess the significance of changes in pre and post-test in the same group.

\section{Results}

Rats in each group underwent an adaptation for one week before the blood sampling to check the levels of LDL. During the adaptation period, mice were given AD2 feed ad libitum and distilled water, with lighting for 12 hours (there was no treatment difference between each groups).

LDL levels between groups of 60 days of dyslipidemia induction showed no significant difference $(p=0.350)$, while LDL levels between groups of 60 days of therapy showed a significant difference $(p=0.006)$. It shows that treatment in this study make a difference significantly. 
Table 1 shows the average rat's body weight after one week of adaptation (baseline).

Table 1: Average rats body weight after adaptation.

\begin{tabular}{|l|l|}
\hline \multicolumn{2}{|l|}{ Average Rats Body Weight After Adaptation } \\
\hline Group & Body weight (grams) \\
\hline I & $115.90 \pm 10.17$ \\
\hline II & $155.66 \pm 17.49$ \\
\hline III & $141.34 \pm 22.97$ \\
\hline IV & $141.40 \pm 17.99$ \\
\hline V & $146.74 \pm 11.12$ \\
\hline $\begin{array}{l}\text { Group I-V: Group given AD2 feed ad libitum and distilled water with lighting for } \\
\text { 12 hours for one week (adaptation). }\end{array}$ \\
\hline
\end{tabular}

Table 2 shows the average rat body weight after 60 days of hyperlipidemic induction and after therapy.

Table 2: Average rats body weight before and after therapy.

\begin{tabular}{|c|c|c|}
\hline \multicolumn{3}{|c|}{ Body Weight Comparison Before and After Therapy } \\
\hline Group & Before therapy (grams) & After therapy (grams) \\
\hline I & $248.44 \pm 13.27$ & $274.72 \pm 16.01$ \\
\hline II & $282.78 \pm 24.81$ & $316.16 \pm 33.16$ \\
\hline III & $306.08 \pm 46.34$ & $343.40 \pm 62.43$ \\
\hline IV & $311.44 \pm 47.03$ & $352.58 \pm 60.84$ \\
\hline $\mathrm{V}$ & $310.52 \pm 36.62$ & $317.60 \pm 46.60$ \\
\hline \multicolumn{3}{|c|}{ Group I: Group given standard feed AD2 } \\
\hline \multicolumn{3}{|c|}{ Group II: Group given a high-fat feed modification AD2 } \\
\hline \multicolumn{3}{|c|}{$\begin{array}{l}\text { Group III: Group given a high-fat feed modification AD2+simvastatin therapy } \\
0.8 \mathrm{mg} / 200 \mathrm{~g} \text { body weight/day }\end{array}$} \\
\hline \multicolumn{3}{|c|}{$\begin{array}{l}\text { Group IV: Group given a high-fat feed+AD } 2 \text { modification therapy meniran } \\
\text { extract } 50 \mathrm{mg} / 200 \mathrm{~g} \text { body weight/day }\end{array}$} \\
\hline \multicolumn{3}{|c|}{$\begin{array}{l}\text { Group V: Group given a high-fat feed+AD2 modification therapy meniran } \\
\text { extract } 100 \mathrm{mg} / 200 \mathrm{~g} \text { body weight/day }\end{array}$} \\
\hline
\end{tabular}

Table 3 shows that LDL levels before and after induction were rise significantly in all group $(p<0.05)$. After 60 days of dyslipidemia induction, group I had the lowest LDL levels, while group III had the highest LDL levels, but the difference was not significant.

Table 3: Comparison of LDL levels after adaptation (Baseline) and 60 days of dyslipidemia induction.

Comparison of LDL Levels After Adaptation (Baseline) and 60 Days of Dyslipidemia Induction

\begin{tabular}{|l|l|l|l|}
\hline Group & $\begin{array}{l}\text { After adaptation } \\
\text { (baseline) }\end{array}$ & $\begin{array}{l}\text { After } \mathbf{6 0} \text { days of } \\
\text { induction }\end{array}$ & P \\
\hline I & $7.92 \pm 1.53$ & $34.3 \pm 3.31$ & 0 \\
\hline II & $12 \pm 2.47$ & $36.94 \pm 5.58$ & 0.043 \\
\hline III & $10.56 \pm 1.86$ & $39.26 \pm 3.76$ & 0 \\
\hline
\end{tabular}

\begin{tabular}{|l|l|l|l|}
\hline IV & $9.06 \pm 1.54$ & $35.42 \pm 5.53$ & 0 \\
\hline $\mathrm{V}$ & $9.18 \pm 2.17$ & $36.78 \pm 3.95$ & 0 \\
\hline $\mathrm{P}$ & 0.017 & 0.35 & - \\
\hline \multicolumn{2}{|l|}{$\begin{array}{l}\text { Group I: Group given standard feed AD2 } \\
\text { Group II-V: Group given a high-fat feed modification AD2 }\end{array}$} \\
\hline
\end{tabular}

Table 4 shows that roughly all LDL levels decreased after 60 days of therapy. The reductions of LDL cholesterol level were significant in all groups $(p<0.05)$, except in group $\mathrm{V}$.

Table 4: Comparison of LDL levels after 60 days of dyslipidemia induction and 60 days of therapy.

\begin{tabular}{|c|c|c|c|}
\hline \multicolumn{4}{|c|}{$\begin{array}{l}\text { Comparison of LDL After } 60 \text { Days of Dyslipidemia Induction and } 60 \text { Days } \\
\text { of Therapy }\end{array}$} \\
\hline Group & $\begin{array}{l}\text { After } 60 \text { days of } \\
\text { induction }\end{array}$ & $\begin{array}{l}\text { After } 60 \text { days of } \\
\text { therapy }\end{array}$ & $\mathbf{P}$ \\
\hline I & $34.3 \pm 3.31$ & $23.08 \pm 2.51$ & 0.003 \\
\hline II & $36.94 \pm 5.58$ & $26.62 \pm 4.83$ & 0.043 \\
\hline III & $39.26 \pm 3.76$ & $25.8 \pm 3.17$ & 0.002 \\
\hline IV & $35.42 \pm 5.53$ & $19.7 \pm 4.10$ & 0.002 \\
\hline V & $36.78 \pm 3.95$ & $30.68 \pm 5.13$ & 0.066 \\
\hline$P$ & 0.35 & 0.006 & - \\
\hline \multicolumn{4}{|c|}{ Group I: Group given standard feed AD2 } \\
\hline \multicolumn{4}{|c|}{ Group II: Group given a high-fat feed modification AD2 } \\
\hline \multicolumn{4}{|c|}{$\begin{array}{l}\text { Group III: Group given a high-fat feed modification AD2+simvastatin therapy } \\
0.8 \mathrm{mg} / 200 \mathrm{~g} \text { body weight/day }\end{array}$} \\
\hline \multicolumn{4}{|c|}{$\begin{array}{l}\text { Group IV: Group given a high-fat feed+AD2 modification therapy meniran } \\
\text { extract } 50 \mathrm{mg} / 200 \mathrm{~g} \text { body weight/day }\end{array}$} \\
\hline \multicolumn{4}{|c|}{$\begin{array}{l}\text { Group V: Group given a high-fat feed+AD } 2 \text { modification therapy meniran } \\
\text { extract } 100 \mathrm{mg} / 200 \mathrm{~g} \text { body weight/day }\end{array}$} \\
\hline
\end{tabular}

\section{Discussion}

Our data shows that Phyllanthus niruri causes a decrease in the serum level of LDL in induced hyperlipemic rats. After 60 days of therapy, the group which received meniran therapy dose $50 \mathrm{mg} / 200 \mathrm{~g}$ body weight/day experienced a significant reduction in LDL. This decrease is parallel with study by Dominiczak which found flavonoids have a protective effect on LDL cholesterol to not be oxidized [9]. Sattanathan et al. stated that Rutin compounds can inhibit lipid peroxidation [10]. According to research by Sattanathan et al., the active compound supplement for 60 days in humans can reduce LDL levels significantly [10]. Odbayar et al. stated that Rutin decreases the activity of HMG-CoA reductase inhibitors and the activity of acyl CoA: cholesteryl acyl transferase (ACAT) thus decreasing hepatic lipogenesis by the liver [11]. Rutin also increases fecal excretion of sterols resulting in reduction of fat absorption. Sudoyo et al. also stated that the decrease in cholesterol synthesis in the liver will also lead to a decrease in the synthesis of Apo B-100 and causing LDL cholesterol in the blood to be drawn to the heart [12]. Nonetheless, meniran therapy dose $100 \mathrm{mg} / 200 \mathrm{~g}$ body weight/day had the smallest decline in LDL level, which was statistically insignificant. 
Compared with the control group, the greater reduction in LDL level was found in meniran dose $50 \mathrm{mg} / 200 \mathrm{~g}$ body weight/day group, and both of them are significant.

The simvastatin treatment group experienced a significant reduction in LDL levels. This result can be due to simvastatin which is a drug that inhibits the HMG-CoA reductase enzyme which is important in the biosynthesis of cholesterol. Due to reduction of cholesterol synthesis, LDL receptors take up more cholesterol from the blood so that cholesterol levels in the blood are reduced. Statins have been shown to decrease the concentration of LDL and triglycerides and slightly raise HDL $[13,14]$.

Compared with the group that was given simvastatin therapy, a greater reduction in LDL level was found in the meniran treatment group receiving $50 \mathrm{mg} / 200 \mathrm{~g}$ body weight/ day, and both of them are significant. When we compared using ANOVA, meniran dose $50 \mathrm{mg} / 200 \mathrm{~g}$ body weight/day can lower LDL cholesterol significantly $(p=0.03)$ compared to the simvastatin therapy group. Meniran dose $100 \mathrm{mg} / 200 \mathrm{~g}$ body weight/day lowered LDL levels but it was statistically insignificant $(p=0.066)$. This insignificant reduction is probably caused by the excessive amount of high-fat feeding that cannot be exactly controlled by ad libitum way of feeding. Tuminah et al. stated that animal fats contain much saturated fatty acids that can increase total cholesterol and LDL levels, and at the same time improve blood HDL cholesterol levels [15]. Trans unsaturated fatty acid contained in animal fat products not only increase LDL cholesterol levels but simultaneously also reduce levels of HDL cholesterol. Further, Dewi explained that the excessive intake of saturated fat causes the insulin sensitivity impairment, so that the blood glucose levels rise. Triglycerides and VLDL particles bind on the position where lipase enzymes work, causing the enzyme to be no longer able to clean the fat [16]. Beside the excessive amount of high-fat feeding, the insignificant result from the meniran treatment group dose $100 \mathrm{mg} / 200 \mathrm{~g}$ body weight/day could also be caused by the antagonistic nature of the active compound meniran at a certain higher doses [17]. Further research is needed to clarify and confirm these important results with more controlled parameters and future clinical human trials.

\section{Conclusion}

Meniran therapy lowers LDL level in hyperlipidemic rats significantly. Meniran extract therapy dose $50 \mathrm{mg} / 200 \mathrm{~g}$ body weight/day gives reduction effects in LDL levels better than meniran dose of $100 \mathrm{mg} / 200 \mathrm{~g}$ body weight/day significantly in Wistar rats. Compared with simvastatin, meniran dose 50 $\mathrm{mg} / 200 \mathrm{~g}$ body weight/day gives better effect in significantly lowering LDL levels in hyperlipidemia induced rat model.

\section{Acknowledgement}

The authors wish to express their gratitude to the Directorate General of Higher Education (DGHE), Ministry of Education and Culture for financial support. The authors also wish to express gratitude to "Klinik Bahasa", Faculty of
Medicine, Public Health and Nursing, Gadjah Mada University, Yogyakarta.

\section{References}

1. World Health Organization (2008) Global Health Observatory Data: Raised Cholesterol.

2. Kamso S (2007) Dislipidemia dan Obesitas Sentral pada Lanjut Usia di Kota Padang. Research Gate 2: 125-132.

3. Murugaiyah V (2008) Phytochemical, Pharmacological and Pharmacokinetic Studies of Phyllantus niruri Linn. Lignans as Potential Antihyperuricemic Agents. Universiti Sains Malaysia.

4. Samali A, Florence DT, Odeniran OA, Cordelia ON (2012) Evaluation of chemical constituents of phyllanthus niruri. Afr J Pharm Pharmacol 6: 125-128.

5. Kahono JY (2010) Pengaruh Ekstrak Herba Meniran (Phyllantus niruri L.) terhadap kadar trigliserida darah tikus putih (Rattus norvegicus). Skripsi, Surakarta, Fakultas Kedokteran Universitas Sebelas Maret.

6. Khanna AK, Rizvi F, Chander R (2002) Lipid Lowering Activity of Phyllanthus niruri in Hyperlipemic Rats. J Ethnopharmacol 82: 19-22.

7. Ministry of Health of Indonesia (1986) Sediaan Galenik, Bakti Husada, Jakarta.

8. Ministry of Health of Indonesia (2005) Pedoman Pemeriksaan Laboratorium Untuk Penyakit Diabetes Melitus. Jakarta.

9. Dominiczak MH (2005) Lipids and Lipoproteins. In: Baynes JW, Dominiczak MH: Medical Biochemistry, (2nd edn) Philadelphia: Elsevier Mosby, pp: 225-243.

10. Sattanathan K, Dhanapal CK, Manavalan R (2010) LDL Lowering properties of rutin in diabetic patients. Int J Pharm Bio sci 1: 467-473.

11. Odbayar T, Demberel B, Toshinori K (2006) Comparative studies of some phenolic compounds (Quercetin, Rutin, and Ferulic Acid) affecting hepatic fatty acid synthesis in mice. J Agric Food Chem 54: 8261-8265.

12. Sudoyo AW, Setiyohadi B, Alwi I, Marcellus S, Setiati S (2007) Buku Ajar Penyakit Dalam, (4 edn), Jakarta.

13. Barter P, Gotto AM, Phil D, LaRosa JC, Maroni J, et al. (2007) HDL cholesterol, very low levels of LDL cholesterol and cardiovascular events. N Engl J Med 357: 1301-1310.

14. Branchi A, Rovellini A, Florenza AM, Maraffi F, Gandini RM, et al. (1996) The effect of simvastatin on HDL cholesterol in hyperlipidemic patients. Evidence of a relationship with the changes in Serum Triglyceride level. Int J Clin Pharmacol Ther 34: 384-389.

15. Tuminah, Sulistyowati (2009) Peran Kolesterol HDL Terhadap Penyakit Kardiovaskuler dan Diabetes Mellitus. Gizi Indon 32: 69-76.

16. Dewi M (2007) Khasiat Penurunan Kadar Glukosa Darah Kombinasi Ekstrak Bulbus Bawang Putih dan Rimpang Kunyit dengan Pembanding Glibenklamid pada Penderita Diabetes Mellitus Tipe 2. Bandung, Institur Teknologi Bandung.

17. Yang Y, Zhang Z, Li S, Ye X, Li X, et al. (2014) Synergy effects of herb extracts: Pharmacokinetics and pharmacodynamic basis. Fitoterapia 92: 133-147. 